\title{
DIRECT CONNECTION PHOTOVOLTAIC SYSTEM IN MULTI-MOTOR APPLICATION FOR THE RURAL SECTOR
}

\author{
André O. Queiroz ${ }^{*}$, Alaan U. Brito ${ }^{1}$ \\ $1^{1 *}$ Corresponding author. UNIFAP - Universidade Federal do Amapá/ Macapá - AP, Brasil. \\ E-mail: andrequeiroz@unifap.br | ORCID: https://orcid.org/0000-0003-1927-8830
}

\section{KEYWORDS}

photovoltaic pumping system with variable speed drive, agricultural equipment, cassava processing (Manihot esculenta Crantz).

\begin{abstract}
Photovoltaic pumping systems equipped with variable speed drive have been consolidated as an alternative for water supply in rural locations where energy services are unavailable. Such systems are of the direct connection type and, therefore, it is likely that their operation occurs in two situations: when energy is available and when the reservoir is full or the available energy is insufficient for pumping water. Thus, this study aimed to evaluate the shared use of a photovoltaic pumping system equipped with a variable speed drive and the motor load of the agricultural equipment (cassava grater). The tests were performed in the laboratory and subsequently in the field, where data of the grated cassava production was collected in periods when the solar radiation is insufficient to pump the water. The results indicate that water can be pumped at an irradiance higher than $375 \mathrm{~W} \mathrm{~m}^{-2}$, while the cassava grater can operate at an irradiance starting from $200 \mathrm{~W}$ $\mathrm{m}^{-2}$. Thus, we could conclude that the agricultural equipment can be used in a photovoltaic pumping system equipped with a variable speed drive in a complementary way such that, besides optimizing the use of energy, it adds a new functionality to the application through the use of agricultural equipment.
\end{abstract}

\section{INTRODUCTION}

Photovoltaic systems are formed by a set of elements that generate and supply electricity by converting the solar energy. In these systems, the configuration and components used can be varied according to the desired application. A photovoltaic pumping system equipped with a variable speed drive (PPS-VSD) consists of a photovoltaic generator, variable speed drive, motor pump with a three-phase induction motor, storage tank, and water distribution system (Valer et al., 2016).

The fact that these systems do not use a battery bank ensures greater reliability, reduces maintenance, avoids environmental pollution due to lead, which is a heavy metal present in most batteries used in autonomous photovoltaic systems, and minimizes the dependence on electricity generated by diesel, gas, or coal (Chandel et al., 2015). However, because the energy cannot be stored in these systems, PPS-VSD should be sized to provide a daily volume of water higher than the daily consumption demand to suffice the days of autonomy, as needed.
According to Valer et al. (2016), in Brazil, the photovoltaic systems were first installed in the state of São Paulo in 2005, resulting from the research of Brito \& Zilles (2005). In this study, the author made adjustments in the PID controller ${ }^{2}$ of commercial variable speed drives to couple centrifugal motor pumps with photovoltaic generators. Based on this proposed configuration, other works of significant relevance were performed in the area.

Fedrizzi et al. (2009) evaluated some applications of photovoltaic pumping systems with variable speed drives in the field, considering local specificities and technology transfer methods. Driemeier \& Zilles (2010) developed a low-cost circuit to monitor the maximum power point of the system, where the input is the voltage of photovoltaic array and the output feeds the PID controller of the system. Their study resulted in an efficiency higher than $98 \%$, as observed on the maximum power tracker.

Maranhão et al. (2015) proposed the application of a Fuzzy controller to the variable speed drive of the photovoltaic pumping system using an Arduino

\footnotetext{
${ }^{1}$ UNIFAP - Universidade Federal do Amapá/ Macapá - AP, Brasil.

${ }^{2}$ PID controller: Process control technique commonly used in industrial control systems. It serves to minimize the error and stabilize the systems.
} 
microcontroller and a light-dependent resistor. Antonello et al. (2016) presented a PPS-VSD configuration using a permanent magnet synchronous motor, maximum power point tracking circuit, and virtual load for the simulations.

Maranhão et al. (2016) conducted the experimental tests of the fuzzy controller on a motor pump test bench, which could simulate water wells with different manometric heights.

Thus, it appears that there are no studies in the literature that optimize the use of energy produced by a PPS-VSD in scenarios where the photovoltaic generator is underutilized. These scenarios include instances of high irradiance and when the water reservoir is full or the available irradiance is insufficient for pumping water. Therefore, it is suggested to share the photovoltaic generation with a second drive load, which belongs to a piece of agricultural equipment that, besides optimizing the energy use, will add new functionalities to the application; for instance, the integration of productive activity with the system. Therefore, the objective of this study is to evaluate the shared use of the photovoltaic generator of pumping photovoltaic systems with a variable speed drive in a multi-motor application.

\section{MATERIAL AND METHODS}

For the elaboration of the research, the configuration of a shared PPS-VSD with an agricultural driving load was proposed. The laboratory tests were performed at the Renewable Energy Laboratory of the Federal University of Amapá, located in the city of Macapá, Amapá, Brazil. The field tests were performed in subdivision 52 of the Agrarian Reform Project of ItaubalAP, where a PPS-VSD is already in operation. The farm is called "Retiro Deus Proverá" and is located at the following geographical coordinates: Latitude- $00^{\circ} 35^{\prime} 37.5^{\prime}$ " $\mathrm{N}$ and Longitude- 50'43'31.7' W. The photovoltaic generator installed in the locality is shown in Figure 1(a), and the structure assembled for the water reservoir is shown in Figure 1(b); this structure serves as a protection house for the power conditioning unit.

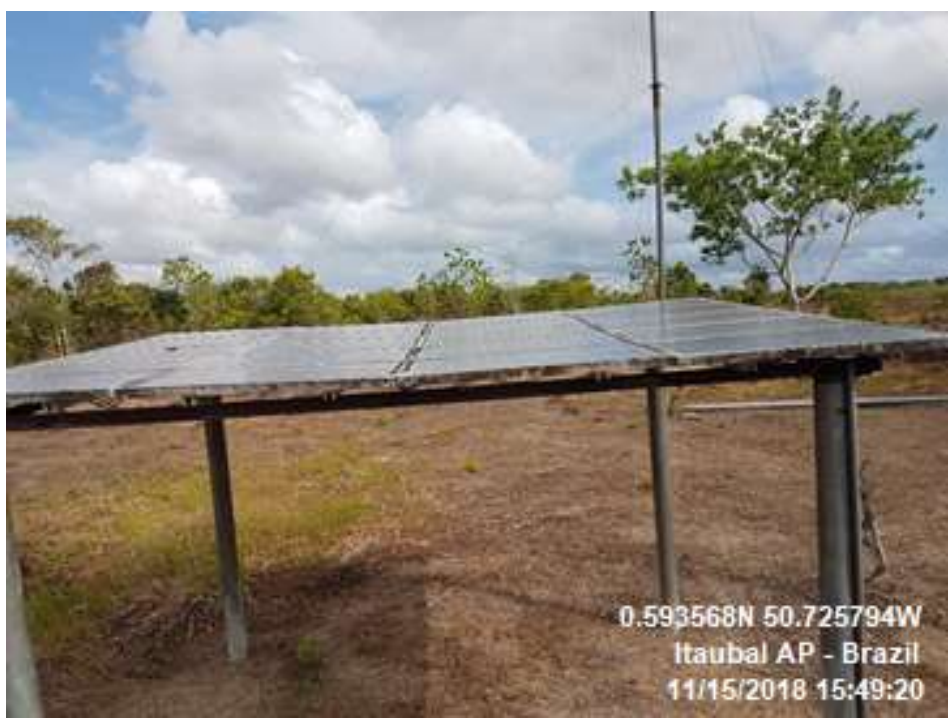

(a)

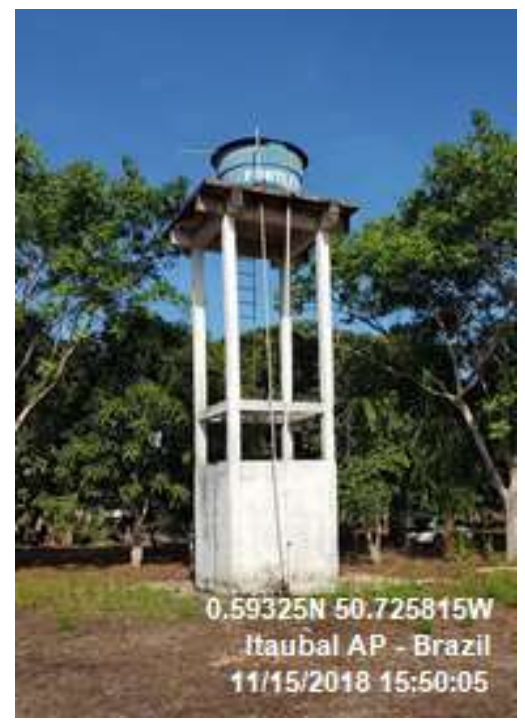

(b)

FIGURE 1. PPS-VSD installed on the farmer's plot.

During the site visit, it was found that the PPSVSD, installed in 2011, was well maintained and in full operation. A semi-artesian well was drilled to a depth of $40 \mathrm{~m}$, and a motor pump was installed at a depth of $18 \mathrm{~m}$. The water reservoir with a capacity of 3,000 L was located on a $5 \mathrm{~m}$-tower built specifically for this application. Considering the depth of the dynamic level of the well, height of the reservoir $(1 \mathrm{~m})$, and losses in the piping, the total manometric height of the project was estimated to be approximately $25 \mathrm{~m}$.

As for the agricultural activity, the farmer informed us that his main source of income was the processing of cassava (Manihot esculenta Crantz). Cassava was processed using a cassava grater, popularly called "caititu" to produce flour and other derivatives, as shown in Figure 2. 


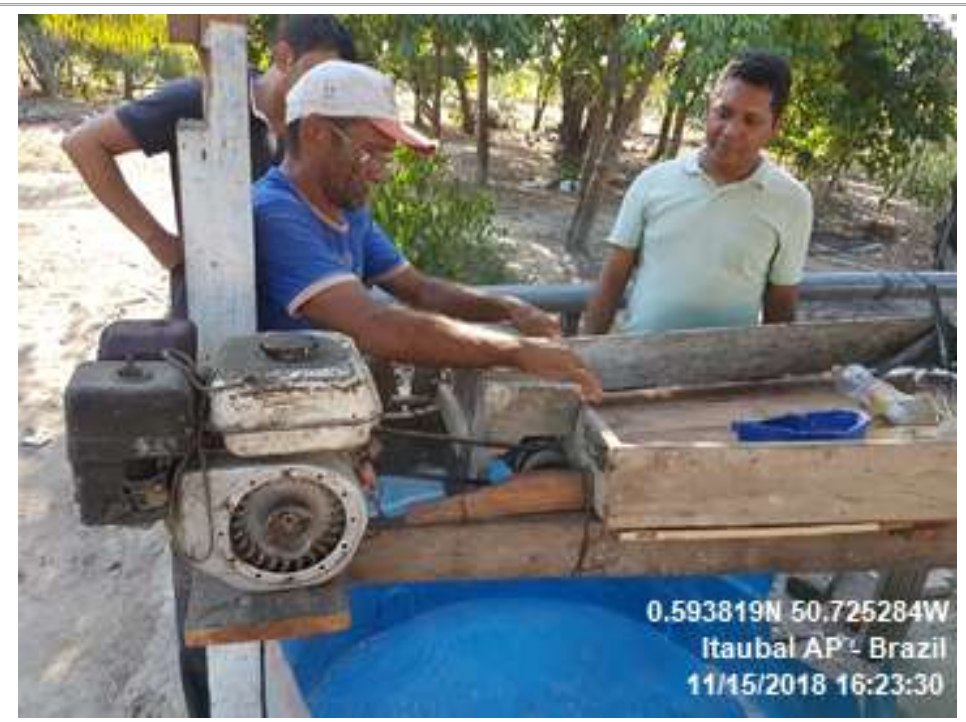

FIGURE 2. Equipment used by the farmer to grate cassava.

The farmer used a 4,048 W-gasoline outboard engine as an alternative to avoid the manual operation of grater. Originally, this engine was used in small boats and is therefore commercially known as the "tail engine." The fact that the farmer was using the engine for an application for which it was not designed had certain consequences: an excessive consumption of gasoline, estimated to be $1.5 \mathrm{~L}$ $\mathrm{h}^{-1}$, and a risk of accidents at work because an engine power that is higher than the requirement was used to perform the activity. For these reasons, we integrated the cassava grater with the existing PPS-VSD by replacing the gasoline engine with a $736 \mathrm{~W}$-three-phase induction engine. In Figure 3, a grater equipped with an electric motor is shown.

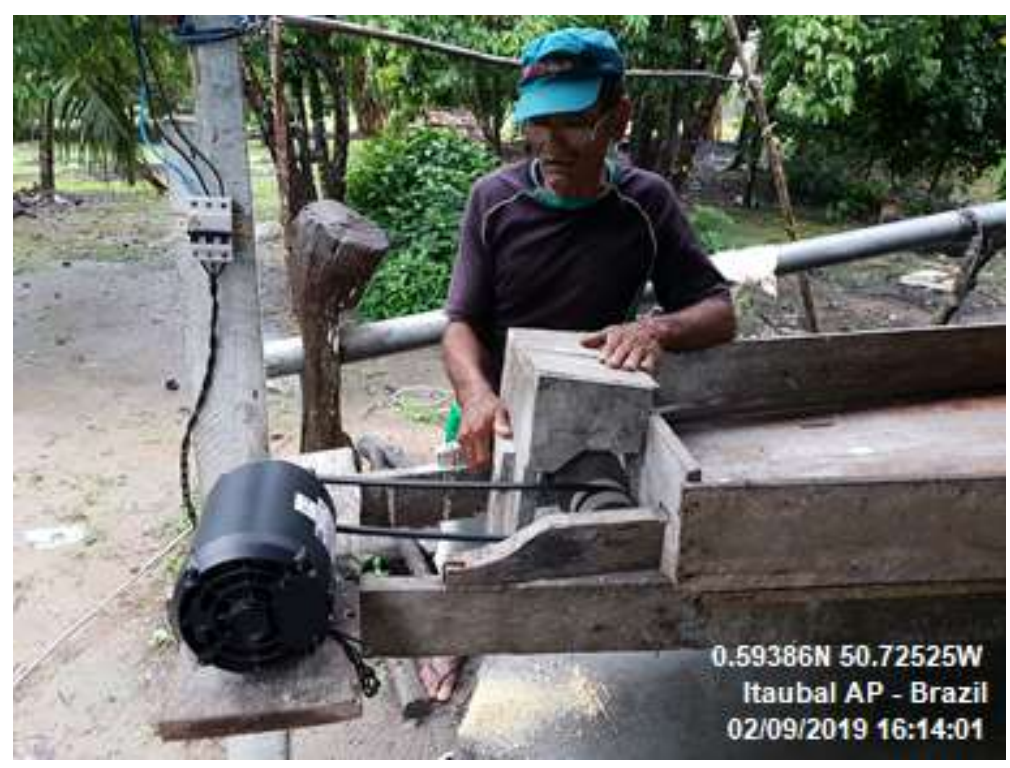

FIGURE 3. Cassava grater equipped with an electric motor instead of the gasoline engine.

In addition, a prototype with a $368 \mathrm{~W}$-engine was built to perform laboratory tests and to analyze the behavior of grater using a lower power engine. The prototype of the grater and electrical panel used in the tests is shown in Figure 4 . 


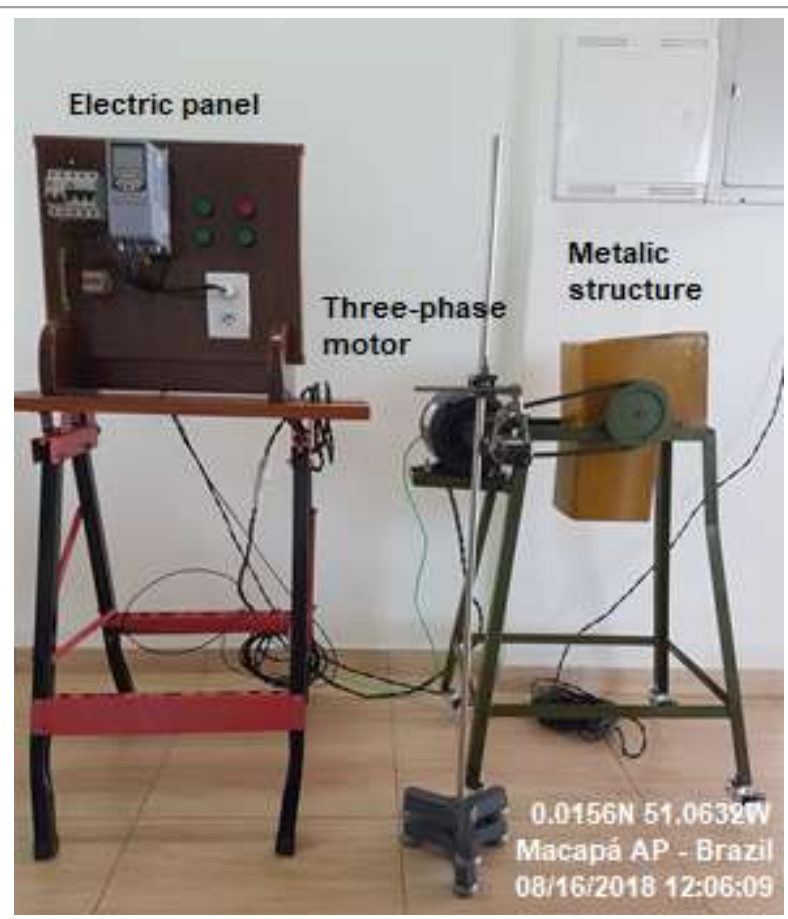

FIGURE 4. Prototype of the electrical panel and $368 \mathrm{~W}$ cassava grater.

The configuration of the integration of the PPS-VSD with the grater is shown in Figure 5.

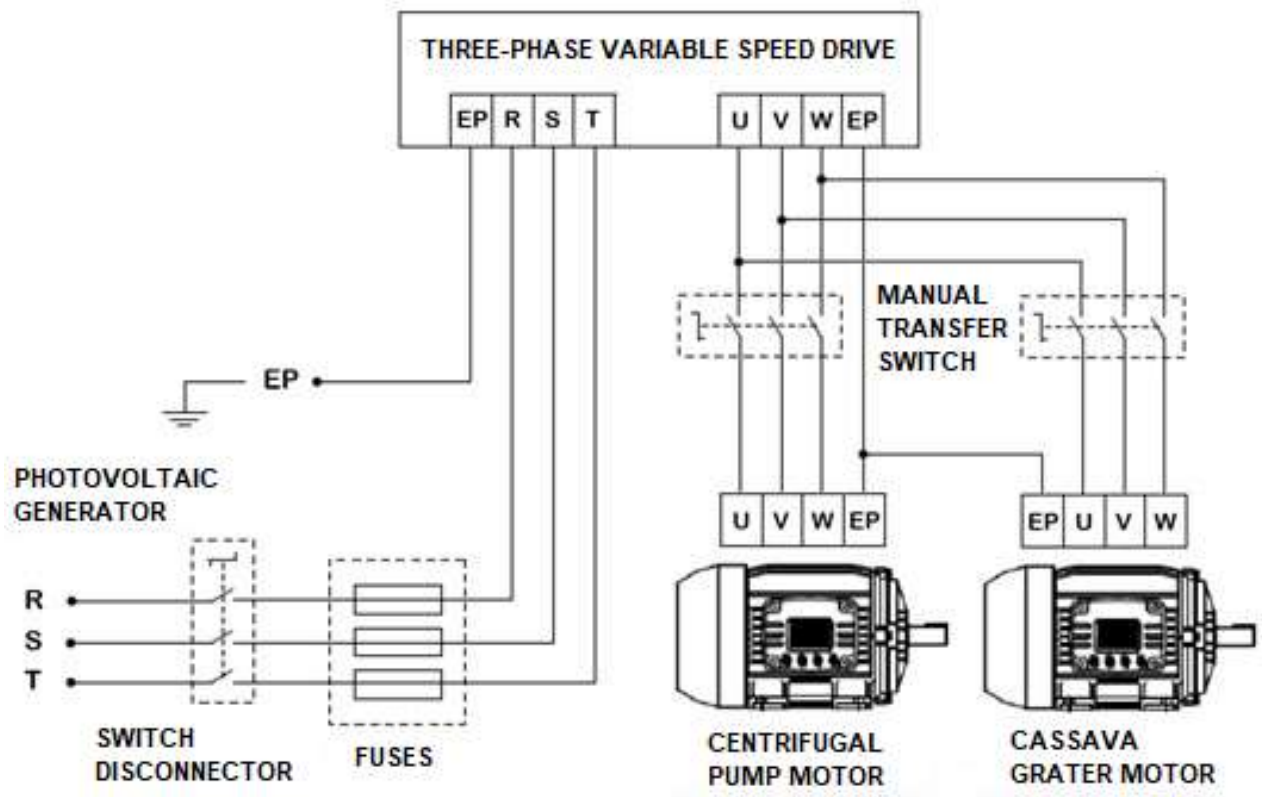

FIGURE 5. Configuration of the integration of the PPS-VSD with the agricultural equipment.

In the figure, $\mathrm{R}, \mathrm{S}$, and $\mathrm{T}$ represent the phases of three-phase electric network; Ep is the Equipotential, where a connection is provided for the system grounding; and $\mathrm{U}$, $\mathrm{V}$, and $\mathrm{W}$ represent the inputs of three-phase motor phases.

In the case of the PPS-VSD, the power is supplied by the photovoltaic generator, and therefore, the input voltage of the system is in direct current. The variable speed drive can be connected to a direct current generator only when the connection is made via the DC link.

The variable speed drive used in this study allows access to the DC link directly through the power terminals. In this way, the $\mathrm{R}$ and $\mathrm{S}$ inputs of the variable speed drive were connected to the photovoltaic generator, where $\mathrm{R}$ and $\mathrm{S}$ were connected to the positive and negative poles, respectively.
The operating voltage range of the variable speed drive, when connected to direct current, was 200-410 Vdc. In this study, 19 photovoltaic modules of $55 \mathrm{Wp}$ each, which corresponds to a maximum power voltage value of $345.8 \mathrm{~V}$, were used.

The system feedback was provided to the PID controller by employing a voltage divider with resistors of $1 \mathrm{M} \Omega$ and $22 \mathrm{k} \Omega$. This was done to ensure that even in an open circuit, the feedback voltage value does not exceed $10 \mathrm{~V}$, which is the limit of the analog input of variable speed drive.

As for the laboratory tests, a cassava grater with a $368 \mathrm{~W}$-motor was installed, and the variable speed drive was connected to the photovoltaic generator installed on 
the roof of the building. The generator consisted of 19 photovoltaic modules (model YL055P-17b 2/5), which were purchased from the Yingli Solar; this was equivalent to a power of $1,045 \mathrm{Wp}$. The total efficiency of this configuration was calculated as $35 \%$.

The configuration and power of the photovoltaic generator installed at the farmer's property were similar to those of the generator installed in the laboratory. However, the photovoltaic generator installed at the farmer's property used the photovoltaic modules of SOLARIS S
55P model. Tests were performed at this location using both a 368 W-engine and 736 W-engine, which represented a total efficiency of $35 \%$ and $70 \%$, respectively. As for the data monitoring, the data logger (Agilent 34970A), calibrated photovoltaic cell (Spektron 210), temperature sensor (PTC 1000), shunt resistor (input $10 \mathrm{~A}$ - output $1000 \mathrm{mV}$ ), and voltage transducer (SECON, input $500 \mathrm{~V}$ - output $10 \mathrm{~V}$ ) sensors were used. The diagram depicting the equipment and sensors used in the electronic instrumentation bench is shown in Figure 6.

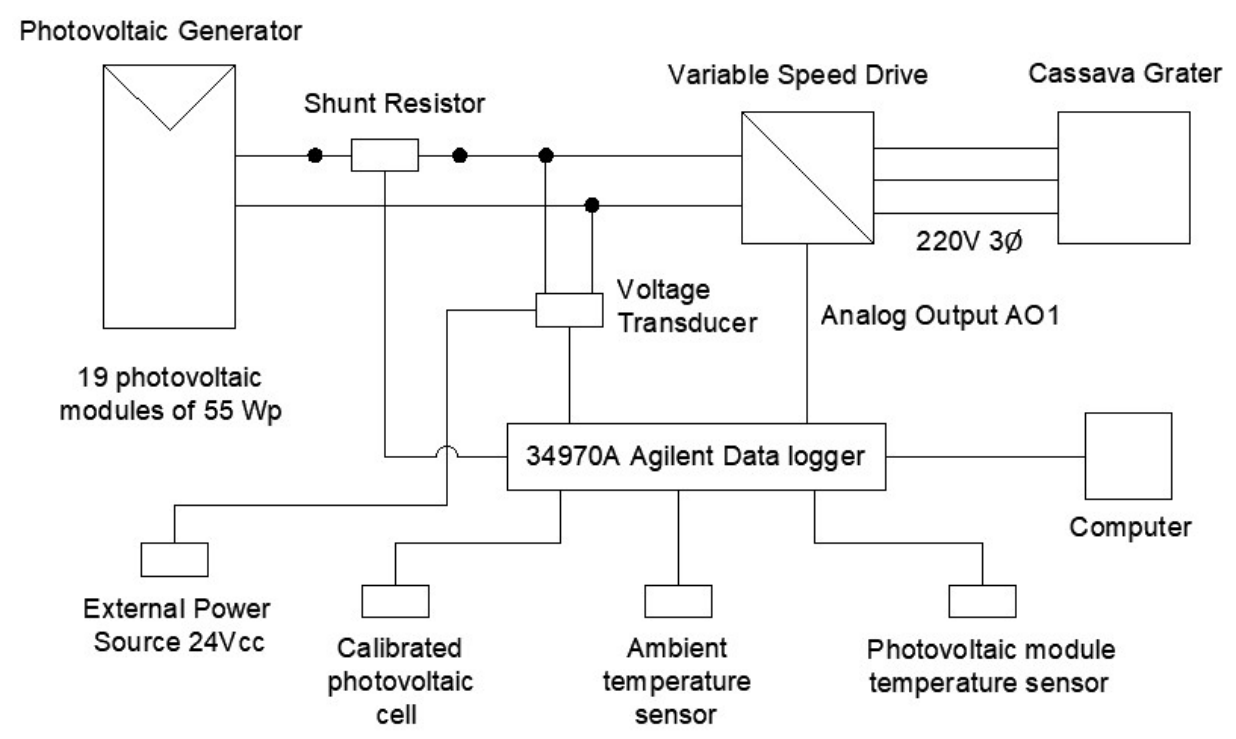

FIGURE 6. Diagram depicting the equipment and sensors used.

Subsequently, programming tests were performed on the variable speed drive (VSD). These tests were conducted to check whether the VSD configuration applied in the PPS-
VSD is compatible with the three-phase induction motor used in cassava grater. The electrical parameters of motors used in the system are shown in Table 1.

TABLE 1. Electrical parameters of motors used in the tests.

\begin{tabular}{cccccccc}
\hline Description & Place & Power (CV) & $\begin{array}{c}\text { Power } \\
(\mathbf{W})\end{array}$ & Rated current & Rotation & Power factor & Efficiency \\
\hline $\begin{array}{c}\text { Three-phase motor pump } \\
\text { (EBARA cod. 4BPS5f-06) }\end{array}$ & PPS-VSD & $3 / 4$ & 552 & $4.9 \mathrm{~A}$ & $3420 \mathrm{RPM}$ & Uninformed & Uninformed \\
$\begin{array}{c}\text { Three-phase motor (WEG } \\
\text { cod. 10021714) }\end{array}$ & Lab & $1 / 2$ & 368 & $1.90 \mathrm{~A}$ & $1730 \mathrm{RPM}$ & 0.73 & $70.0 \%$ \\
$\begin{array}{c}\text { Three-phase motor (WEG } \\
\text { cod. 12216002) }\end{array}$ & PPS-VSD & 1 & 736 & $3.26 \mathrm{~A}$ & $1740 \mathrm{RPM}$ & 0.75 & $80.5 \%$ \\
\hline
\end{tabular}

The programming performed on the WEG CFW500 - variable speed drive used for the operation in the PPS-VSD and cassava grater is shown in Table 2. 
TABLE 2. Programming performed on CFW500 for the operation in the PPS-VSD and cassava grater.

\begin{tabular}{|c|c|c|c|}
\hline Parameter & Function & Factory adjustment & Adjustment applied \\
\hline P0100 & Acceleration time & $10.0 \mathrm{~s}$ & $1.0 \mathrm{~s}$ \\
\hline P0101 & Deceleration time & $10.0 \mathrm{~s}$ & $1.0 \mathrm{~s}$ \\
\hline $\mathrm{P} 0121$ & Reference via HMI & $3.0 \mathrm{~Hz}$ & $60.0 \mathrm{~Hz}$ \\
\hline $\mathrm{P} 0134$ & Maximum speed & $66.0 \mathrm{~Hz}$ & $60.0 \mathrm{~Hz}$ \\
\hline $\mathrm{P} 0135$ & Maximum output current & $1.5 \times \mathrm{P} 0401$ & $7.0 \mathrm{~A}$ \\
\hline P0156 & Overload current $100 \%$ & $1.1 \times \mathrm{P} 0401$ & $5.4 \mathrm{~A}$ \\
\hline P0157 & Overload current $50 \%$ & $1.0 \times \mathrm{P} 0401$ & $4.9 \mathrm{~A}$ \\
\hline $\mathrm{P} 0158$ & Overload current $5 \%$ & $0.8 \times \mathrm{P} 0401$ & $3.9 \mathrm{~A}$ \\
\hline P0203 & Special function selection & $0=$ None & $1=\mathrm{PID}$ via AI1 \\
\hline $\mathrm{P} 0220$ & Local/Remote selection & $2=$ HMI key (LOC) & 3 = HMI key (REM) \\
\hline $\mathrm{P} 0222$ & Remote reference selection & $1=\mathrm{AI} 1$ & $10=$ No Function \\
\hline P0297 & Switching frequency & $5,000 \mathrm{~Hz}$ & $15,000 \mathrm{~Hz}$ \\
\hline P0320 & Flying start/Ride-through & $0=$ Inactive & $2=\mathrm{FS} / \mathrm{RT}$ \\
\hline P0331 & Voltage ramp & $2.0 \mathrm{~s}$ & $10.0 \mathrm{~s}$ \\
\hline P0340 & Auto-reset time & $0 \mathrm{~s}$ & $30 \mathrm{~s}$ \\
\hline P0399 & Motor rated performance & $75.00 \%$ & $70.0 \%$ \\
\hline P0401 & Motor rated current & $1.0 \times \mathrm{P} 0295$ & $4.9 \mathrm{~A}$ \\
\hline P0402 & Motor rated rotation & 1710 RPM & 3420 RPM \\
\hline P0404 & Motor rated power & $8=3.00 \mathrm{HP}(2.20 \mathrm{~kW})$ & $5=1.00 \mathrm{HP}(0.75 \mathrm{~kW})$ \\
\hline P0407 & Motor rated power factor & 0.8 & 0.75 \\
\hline $\mathrm{P} 0521$ & PID integral gain & 0.43 & 0.666 \\
\hline P0525 & PID setpoint by HMI & $0.00 \%$ & $54.00 \%$ \\
\hline $\mathrm{P} 0527$ & PID action type & $0=$ Direct & $1=$ Reverse \\
\hline $\mathrm{P} 0536$ & P0525 Automatic setting & $0=$ Inactive & $1=$ Active \\
\hline
\end{tabular}

The first test of the system was performed in the laboratory, in September 2018. For the experiment, $10 \mathrm{~kg}$ of cassava was used. In addition, weather conditions and electrical parameters were monitored, and the production of cassava per minute was monitored at 2-h intervals. The data obtained from the test of the cassava grater with a $368 \mathrm{~W}$-engine are presented in Table 3.

TABLE 3. Data obtained from the system operating at full load (with a mechanical load applied to the axle) and empty load.

\begin{tabular}{|c|c|c|c|c|c|c|c|c|}
\hline $\begin{array}{l}\text { Schedule } \\
\text { (h) }\end{array}$ & $\begin{array}{c}\text { Irradiance } \\
\left(\mathbf{W} \mathbf{m}^{-2}\right)\end{array}$ & $\begin{array}{c}\text { Empty } \\
\text { input } \\
\text { power }(W)\end{array}$ & $\begin{array}{c}\text { Input power } \\
\text { with } \\
\text { mechanical } \\
\text { load }(W)\end{array}$ & $\begin{array}{c}\text { Ambient } \\
\text { Temp }\left({ }^{\circ} \mathrm{C}\right)\end{array}$ & $\begin{array}{c}\text { Module } \\
\text { Temp }\left({ }^{\circ} \mathrm{C}\right)\end{array}$ & $\begin{array}{c}\text { Empty } \\
\text { Freq. } \\
\text { (Hz) }\end{array}$ & $\begin{array}{c}\text { Freq. with } \\
\text { mechanical } \\
\text { load }(\mathrm{Hz})\end{array}$ & $\begin{array}{c}\text { Cassava } \\
\text { production } \\
\left(\mathrm{g} \mathrm{min}^{-1}\right)\end{array}$ \\
\hline 08:00 & 411.76 & 163.82 & 292.09 & 34.03 & 41.47 & 60 & 59.10 & $1,079.00$ \\
\hline 10:00 & 718.07 & 149.55 & 338.14 & 36.12 & 47.83 & 60 & 59.00 & $1,389.00$ \\
\hline $12: 00$ & 872.26 & 155.02 & 375.33 & 36.70 & 52.73 & 60 & 58.63 & $1,941.00$ \\
\hline $14: 00$ & 755.91 & 144.51 & 315.21 & 39.24 & 53.12 & 60 & 59.16 & $1,573.00$ \\
\hline $16: 00$ & 472.01 & 149.82 & 340.18 & 37.02 & 44.79 & 60 & 59.88 & $1,376.00$ \\
\hline Mean & 647.93 & 152.57 & 332.25 & 36.62 & 47.99 & 60 & 59.15 & $1,472.60$ \\
\hline
\end{tabular}

The second test was performed at the farmer's property, in November 2018. In this test, the same equipment, as the one in the laboratory test, was used, and its objective was to verify the performance of the system in both cases. The test was performed continuously, and the mean values of the monitored parameters were calculated. The data obtained is shown in Table 4. 
TABLE 4. Data obtained from the $368 \mathrm{~W}$-cassava grater installed on the farm.

\begin{tabular}{|c|c|c|c|c|c|c|c|}
\hline $\begin{array}{l}\text { Schedule } \\
\text { (h) }\end{array}$ & Measurements & $\begin{array}{l}\text { Irradiance } \\
\quad\left(\mathrm{W} \mathbf{m}^{-2}\right)\end{array}$ & $\begin{array}{l}\text { Empty input } \\
\text { power }(W)\end{array}$ & $\begin{array}{l}\text { Input power with } \\
\text { mechanical load } \\
(W)\end{array}$ & $\begin{array}{c}\text { Ambient } \\
\text { Temp }\left({ }^{\circ} \mathrm{C}\right)\end{array}$ & $\begin{array}{c}\text { Freq. with } \\
\text { mechanical load } \\
(\mathrm{Hz})\end{array}$ & $\begin{array}{c}\text { Cassava } \\
\text { production } \\
\left(\mathrm{g} \mathrm{min}^{-1}\right)\end{array}$ \\
\hline \multirow{3}{*}{$15: 40-15: 44$} & Minimum & 642.60 & \multirow{2}{*}{159.26} & \multirow{2}{*}{372.24} & 34.32 & \multirow{2}{*}{60} & \multirow{2}{*}{$5,250.00$} \\
\hline & 4 Maximum & 684.39 & & & 35.49 & & \\
\hline & Mean & 663.49 & 159.26 & 372.24 & 34.91 & 60 & $1,312.50$ \\
\hline
\end{tabular}

The third test was performed at the farm, in February 2019. This test was conducted to verify the functioning of the cassava grater installed with a wooden structure and $736 \mathrm{~W}$-engine, where the water was pumped using the motor pump. Another important step is that the prototype was analyzed during heavy rains in the region. The data obtained from the test are shown in Table 5.

TABLE 5. Data obtained from the $736 \mathrm{~W}$-cassava grater operating in the rainy season.

\begin{tabular}{|c|c|c|c|c|c|c|c|}
\hline $\begin{array}{l}\text { Schedule } \\
\text { (h) }\end{array}$ & Measurements & $\begin{array}{c}\text { Irradiance } \\
\left(\mathbf{W} \mathbf{m}^{-2}\right)\end{array}$ & $\begin{array}{c}\text { Empty } \\
\text { input } \\
\text { power }(W)\end{array}$ & $\begin{array}{c}\text { Input power } \\
\text { with } \\
\text { mechanical } \\
\text { load }(W)\end{array}$ & $\begin{array}{l}\text { Ambient Temp } \\
\left({ }^{\circ} \mathrm{C}\right)\end{array}$ & $\begin{array}{c}\text { Freq. with } \\
\text { mechanical } \\
\text { load }(\mathrm{Hz})\end{array}$ & $\begin{array}{c}\text { Cassava } \\
\text { production } \\
\left(\mathrm{g} \mathrm{min}^{-1}\right)\end{array}$ \\
\hline \multirow{3}{*}{$14: 33-14: 48$} & Minimum & 198.94 & \multirow{2}{*}{126.40} & \multirow{2}{*}{189.96} & 24.60 & 21 & \multirow{2}{*}{$9,000.00$} \\
\hline & Maximum & 351.83 & & & 24.80 & 33 & \\
\hline & Mean & 275.38 & 126.40 & 189.96 & 24.70 & 27 & 600.00 \\
\hline
\end{tabular}

During the fourth (final) test, which was performed in March 2019, the system was operated to meet the daily demand of farmers for grated cassava and was monitored. The measurements are shown in Table 6.

TABLE 6. Data obtained from the $736 \mathrm{~W}$-cassava grater operating to meet the farmer's demand.

\begin{tabular}{|c|c|c|c|c|c|c|c|}
\hline $\begin{array}{l}\text { Schedule } \\
\text { (h) }\end{array}$ & Measurements & $\begin{array}{l}\text { Irradiance } \\
\quad\left(\mathrm{W} \mathbf{m}^{-2}\right)\end{array}$ & $\begin{array}{c}\text { Empty } \\
\text { input } \\
\text { power }(W)\end{array}$ & $\begin{array}{c}\text { Input power } \\
\text { with mechanical } \\
\text { load }(W)\end{array}$ & $\begin{array}{c}\text { Ambient Temp } \\
\qquad\left({ }^{\circ} \mathrm{C}\right)\end{array}$ & $\begin{array}{l}\text { Freq. with } \\
\text { mechanical } \\
\text { load }(\mathrm{Hz})\end{array}$ & $\begin{array}{c}\text { Cassava } \\
\text { production } \\
\left(\mathrm{g} \mathrm{min}^{-1}\right)\end{array}$ \\
\hline \multirow{3}{*}{$10: 54-11: 01$} & Minimum & 322.37 & \multirow{2}{*}{236.60} & \multirow{2}{*}{270.67} & \multirow{2}{*}{26.70} & \multirow{2}{*}{60} & \multirow{2}{*}{13,500} \\
\hline & Maximum & 345.01 & & & & & \\
\hline & Mean & 333.69 & 236.60 & 270.67 & 26.70 & 60 & $1,928.57$ \\
\hline \multirow{3}{*}{$14: 10-14: 40$} & Minimum & 220.44 & \multirow{2}{*}{156.31} & \multirow{2}{*}{200.60} & 24.60 & 42 & \multirow{2}{*}{35,700} \\
\hline & Maximum & 259.22 & & & 25.30 & 49 & \\
\hline & Mean & 239.83 & 156.31 & 200.60 & 24.90 & 45.5 & $1,190.00$ \\
\hline
\end{tabular}

The data obtained from the tests were analyzed with the help of Crearray software, which was prepared by the Federal University of Rio Grande do Sul. This software analyzes the photovoltaic arrangements in different types of configurations.

The temperature of the photovoltaic cell was obtained using the equation suggested by Yahyaoui et al. (2017), which employs the ambient temperature, as shown in the following:

$$
T_{c}=T_{a}+H_{t . \beta}\left(\frac{T N O C-20}{800}\right)
$$

In which:

$$
\text { Tc - cell temperature, }{ }^{\circ} \mathrm{C} \text {; }
$$

Ta - ambient temperature, ${ }^{\circ} \mathrm{C}$;

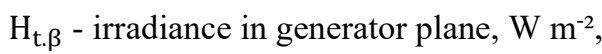

TNOC - nominal cell operating temperature, ${ }^{\circ} \mathrm{C}$.

\section{RESULTS AND DISCUSSION}

The temperature of photovoltaic cells was estimated using the data obtained from tests 1 and 2 and equation (1), and was calculated as approximately $50{ }^{\circ} \mathrm{C}$. The power curves of the photovoltaic generator obtained at a temperature of $50{ }^{\circ} \mathrm{C}$, standard irradiance of $1,000 \mathrm{~W} \mathrm{~m}^{-2}$, measured irradiances, and points where the highest power was required from the photovoltaic generator in the tests, are presented in Figure 7. 


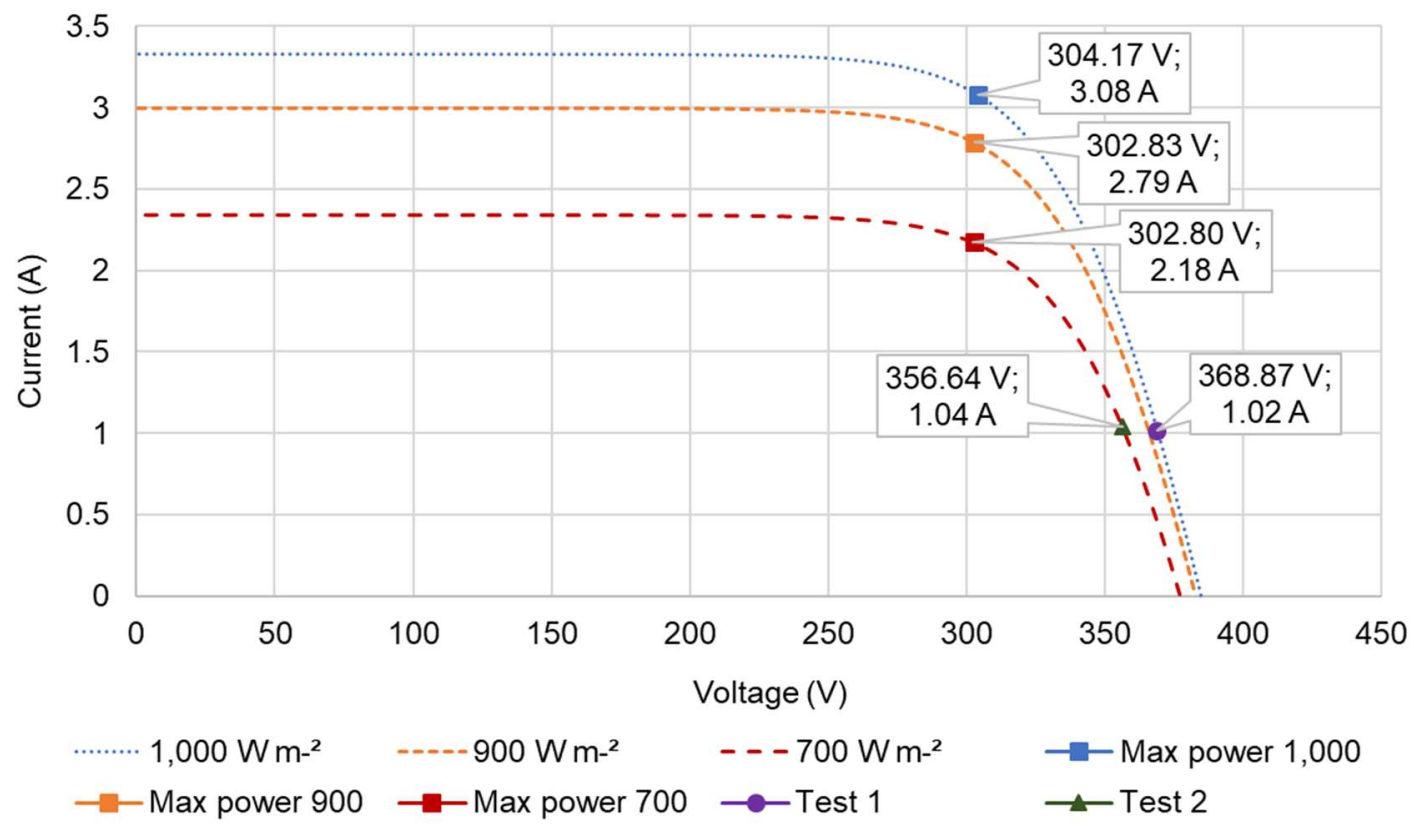

FIGURE 7. Power curves of photovoltaic generator $(1,045 \mathrm{Wp})$ at $50{ }^{\circ} \mathrm{C}$.

From the curves, it was verified that the $368 \mathrm{~W}$ cassava grater consumed lower power than that available from the system, even when operating at the nominal power. Therefore, it is compatible with this application. To confirm this statement, a more detailed analysis of test 1, where the data was collected at 30min intervals, was conducted, and the results are presented in Figure 8.

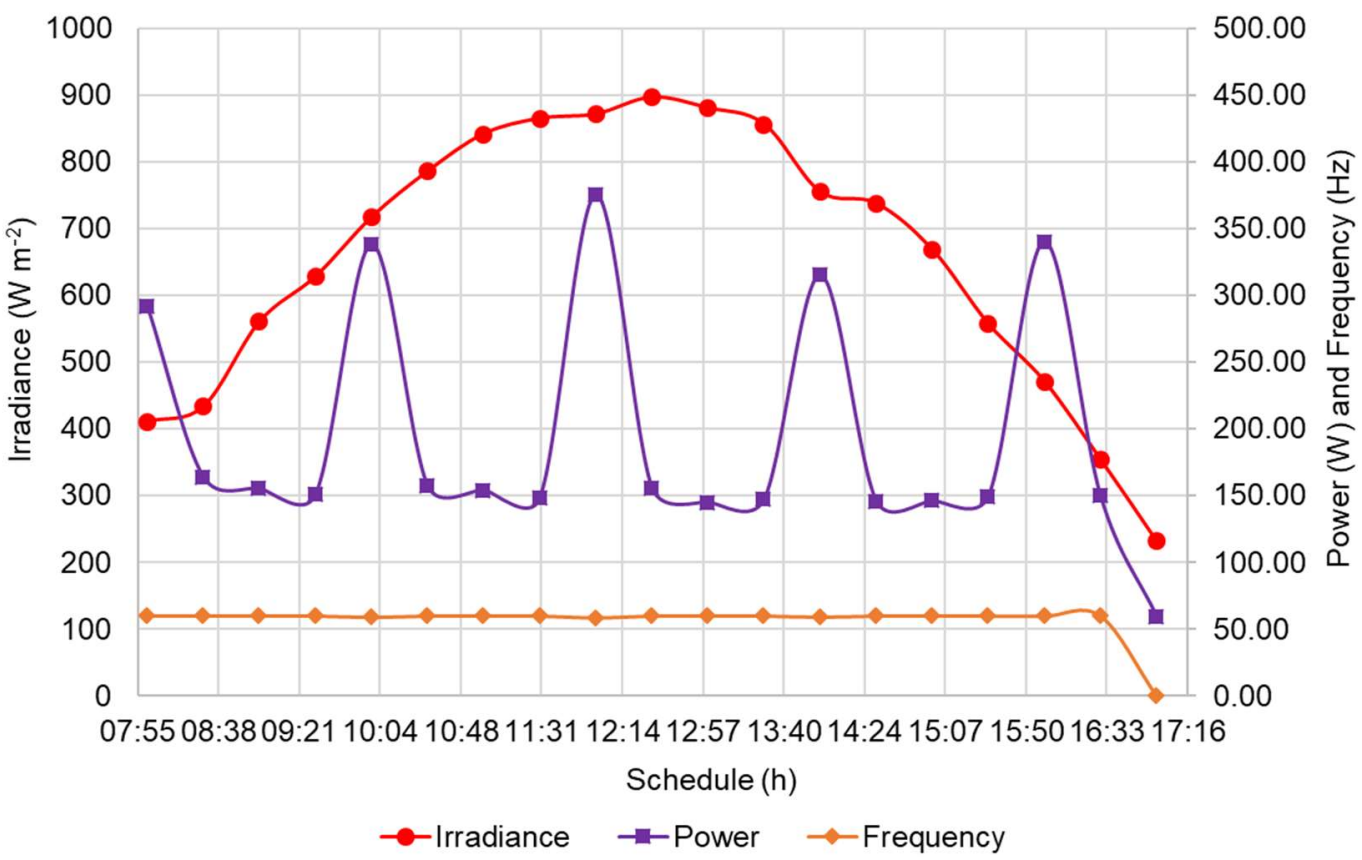

FIGURE 8. Cassava grater data collection at $1 / 2 \mathrm{CV}$ from test 1.

The peaks displayed in the power curve represent the grating of cassava, and the other points represent the empty operation of engine. Note that by employing the graphs in Figures 7 and 8, it can be observed that at certain points, the power supplied to the $368 \mathrm{~W}$-engine exceeds its nominal power, whose maximum value is $7.58 \mathrm{~W}$, as measured from the irradiance curve of $900 \mathrm{~W} \mathrm{~m}^{-2}$ of test 1 .

Thus, additional tests were performed on the engine, and it was found that the overvoltage occurs when irradiance is higher than $700 \mathrm{~W} \mathrm{~m}^{-2}$. To solve this issue, two solutions were proposed:

- Change the power of the pump and grater engine to values close to or higher than that of the photovoltaic generator.

- Change the maximum voltage of the VSD scalar control to protect the lower power motor of the system, which in this case is $368 \mathrm{~W}$-motor. 
The suggested calibration for the $368 \mathrm{~W}$-motor in the WEG CFW500 - variable speed drive was to change the parameter "P0142 - Maximum output voltage" from 100\% to $77.5 \%$. This value was obtained from the tests performed at $12: 00 \mathrm{~h}$ with a mean irradiance of $922.80 \mathrm{~W} \mathrm{~m}^{-2}$ by manually changing the parameter until the value at which the VSD stabilized the output voltage and current according to the nominal voltage and current of the motor was found.

As for tests 3 and 4, the power curves of the photovoltaic generator obtained using the hardened modules at $35^{\circ} \mathrm{C}$, standard irradiance of $1,000 \mathrm{~W} \mathrm{~m}^{-2}$, and measured irradiances are presented in Figure 9.

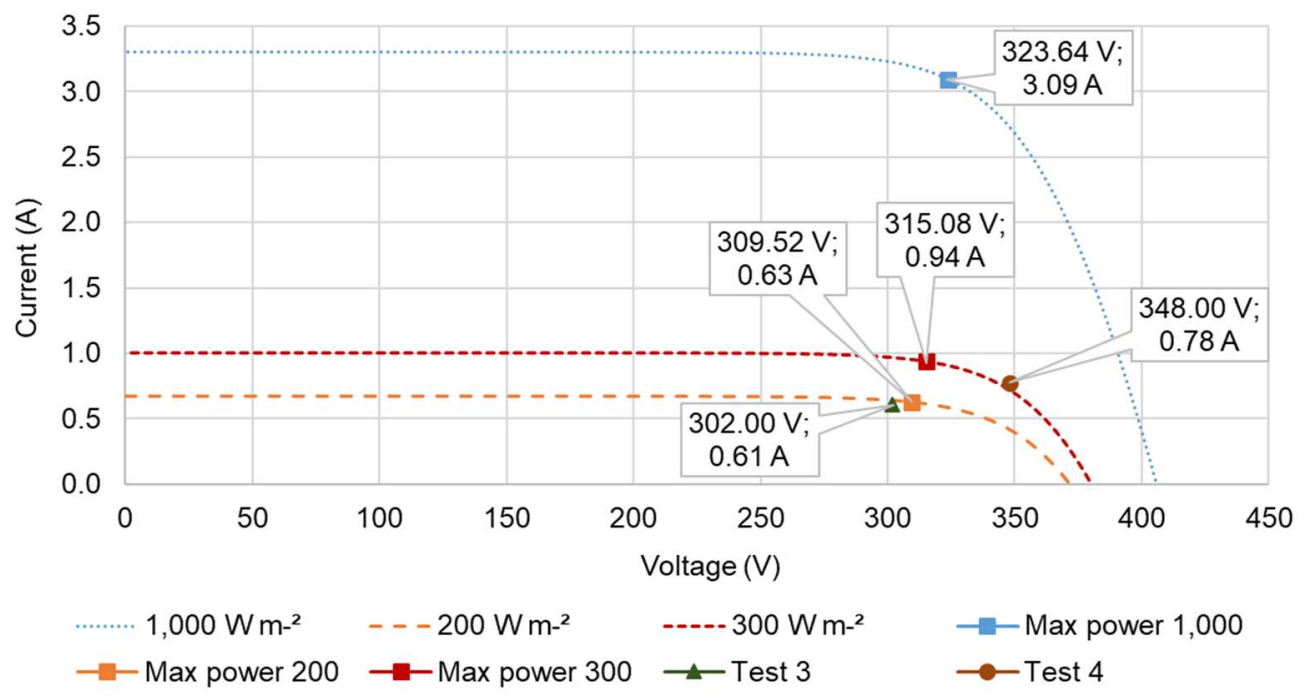

FIGURE 9. Power curves of photovoltaic generator $(1,045 \mathrm{Wp})$ at $35^{\circ} \mathrm{C}$.

These tests were performed in the rainy season. From the power curve of the photovoltaic generator operating at an irradiance of $200 \mathrm{~W} \mathrm{~m}^{-2}$ (test 3), it was verified that the cassava grater could operate even at low irradiances and consumed $184.22 \mathrm{~W}$ out of $195 \mathrm{~W}$ available in the photovoltaic generator. Thus, we can infer that this equipment is compatible with the desired application. It can be observed that regardless of the irradiance, the PID controller tends to make the system operate near the point of maximum power.
As for the integration of the cassava grater with the PPS-VSD, this study proposes to share the use of available energy at the output of the variable speed drive in periods when the reservoir is full or when the available irradiance is insufficient for pumping water. Thus, during test 3 , the operation of the motor pump in the PPS-VSD was verified, and the data collected every $10 \mathrm{~min}$ are shown in Figures 10 and 11 .

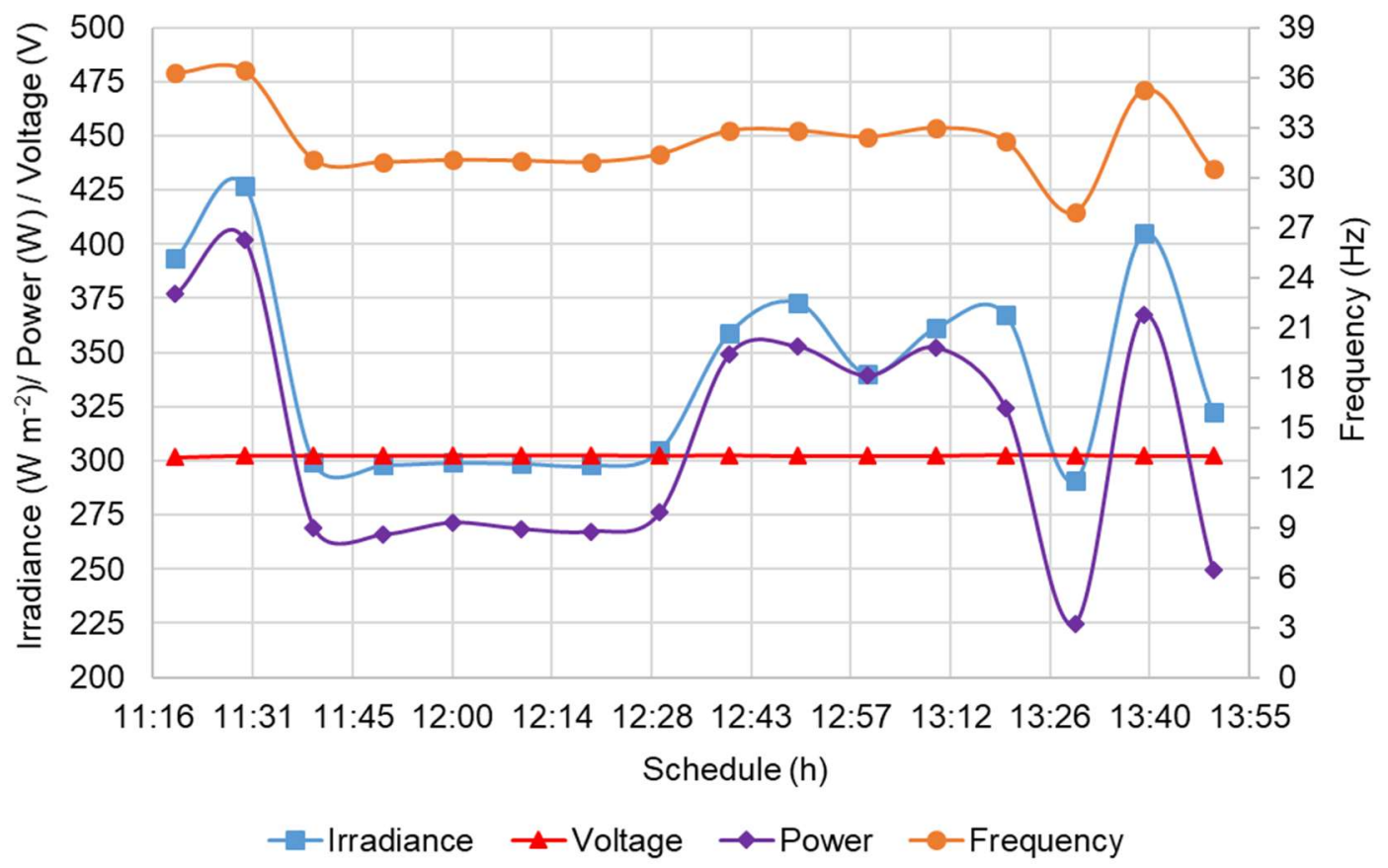

FIGURE 10. Motor pump data collection during test 3. 


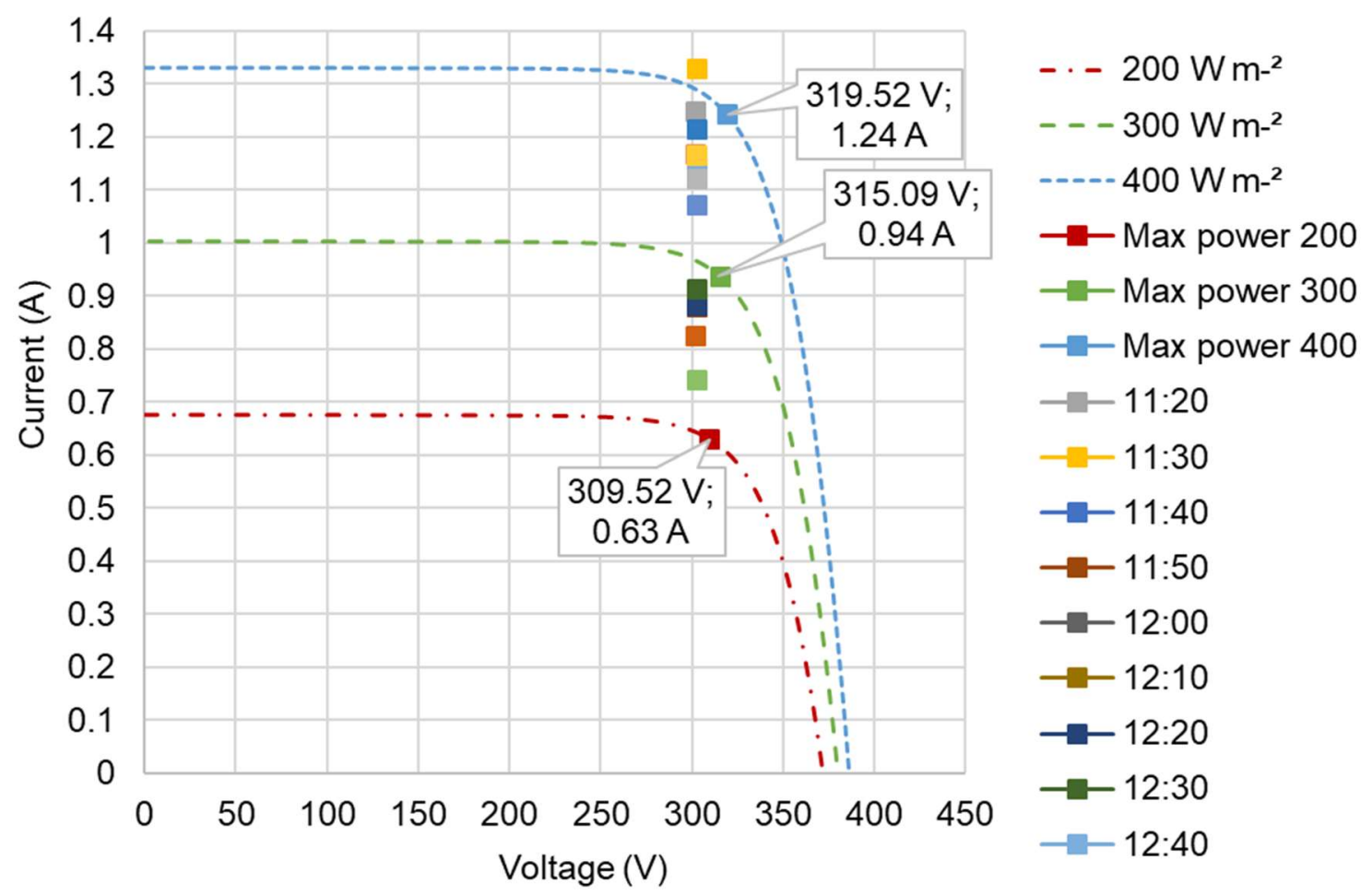

FIGURE 11. Motor pump operation in different irradiance scenarios.

In this test, it was found that in scenarios where irradiance was lower than $375 \mathrm{~W} \mathrm{~m}^{-2}$, i.e., frequencies lower than $32 \mathrm{~Hz}$ in the motor pump, no water was pumped although the engine was running. In addition, it was noticed that the voltage in the DC link was stabilized at approximately $300 \mathrm{~V}$ in a region close to the maximum power point of the photovoltaic generator, as shown in Figure 11. Further, the power consumed and frequency in the motor pump vary according to irradiance; this confirms the appropriate operation of the PID controller in the system.

The power consumed by the $552 \mathrm{~W}$-motor pump and $736 \mathrm{~W}$-cassava grater operating under empty load was compared with the power curve of the $1 \mathrm{kWp}$ photovoltaic generator, estimated using the Crearray software. This analysis was performed during test 4 and, the results are shown in Figure 12.

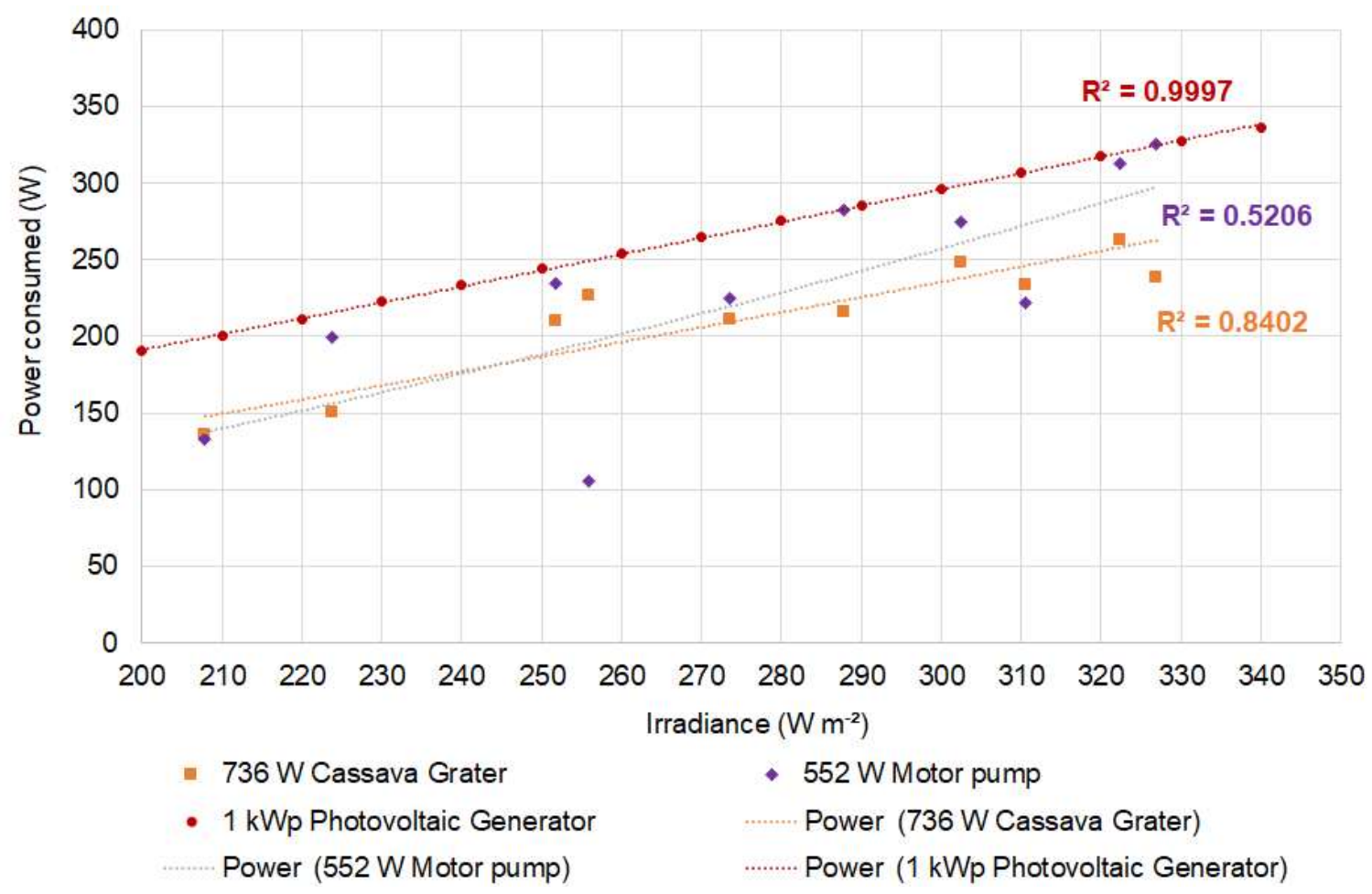

FIGURE 12. Comparison of the power consumed by the motor pump and cassava grater with the power of the $1 \mathrm{kWp}$ photovoltaic generator. 
From Figure 12, it is evident that there is a significant variation in the power of the motor pump, while in the cassava grater, a better accuracy of the data is obtained $\left(\mathrm{R}^{2}=0.8402\right)$. This is because, as shown in Figure 10, the electric voltage tends to be constant in the system and the power consumed varies according to the change in electric current that occurs during the test.

Because the motor is submerged, it is not possible to determine the nature of the vibration, i.e., as to why a torque variation is required by the application. Therefore, it is recommended that a future study be conducted in a laboratory, for a detailed characterization of the motor pump power curve with a manometric height similar to that of this system.

In addition, it was found that in low irradiance scenarios (below $330 \mathrm{~W} \mathrm{~m}^{-2}$ ), the $736 \mathrm{~W}$-engine of the cassava grater requires a lower power than that of the motor pump to operate and exhibits normal operation in all the tested periods, but with reduced speed. Therefore, it is suitable for integration with the PPS-VSD and for operation in scenarios where water is not pumped.

The relationship between the irradiance and grated cassava production for the $368 \mathrm{~W}$-engine is shown in Figure 13, and the same relationship for the $736 \mathrm{~W}$-engine is shown in Figure 14.

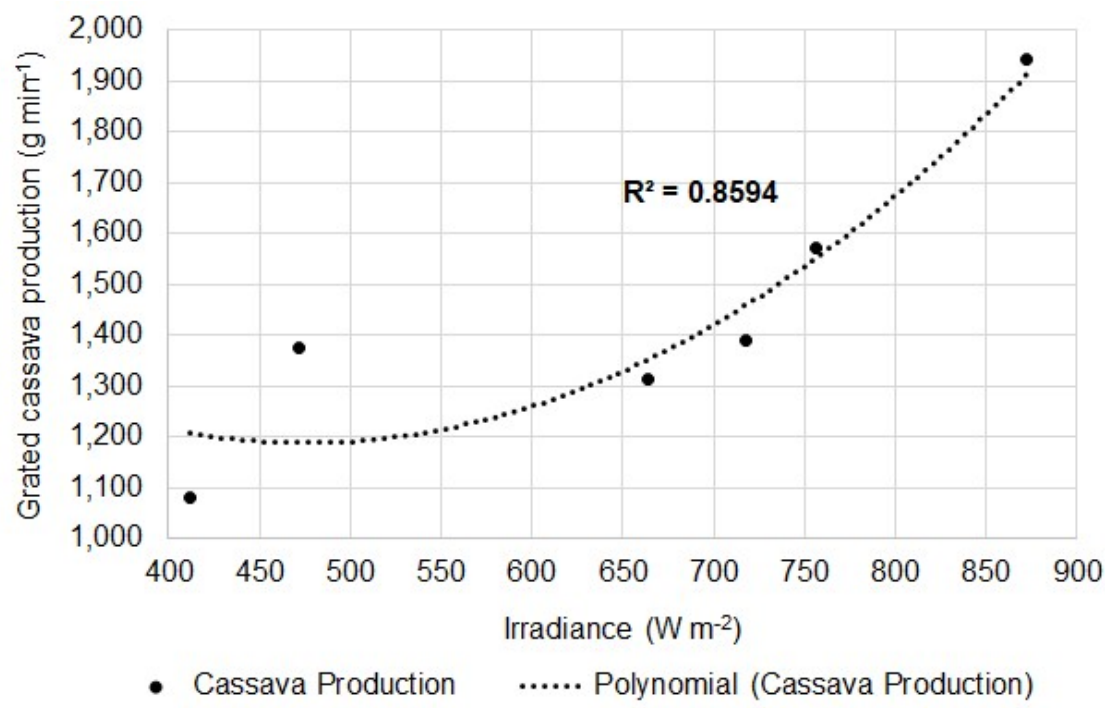

FIGURE 13. Production of grated cassava $\left(\mathrm{g} \mathrm{min}^{-1}\right)$ estimated for the $368 \mathrm{~W}$-engine.

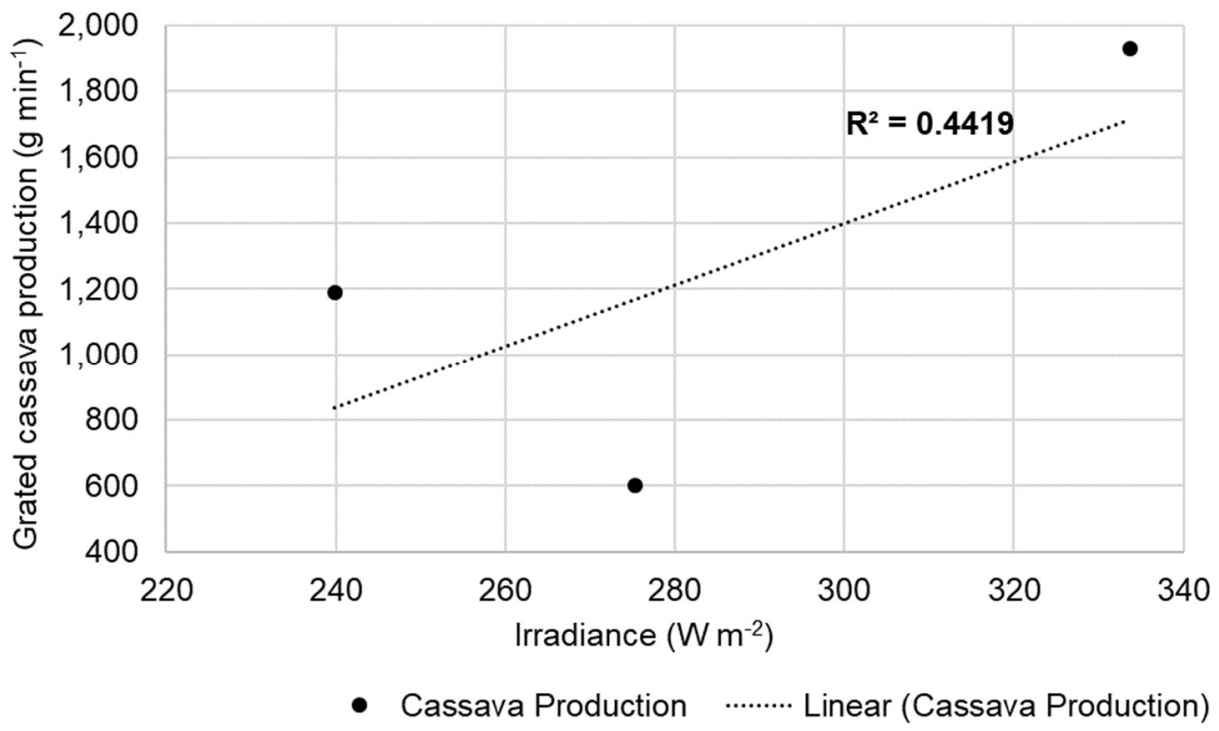

FIGURE 14. Production of grated cassava $\left(\mathrm{g} \mathrm{min}^{-1}\right)$ estimated for the $736 \mathrm{~W}$-engine.

The difference in the $\mathrm{R}^{2}$ values of tests can be attributed to the challenges associated with collecting these data in the field, such as measurements on different days and times, the use of means, uneven operation of the grater by farmers, diversity in size and volume of the cassava used for grating, reduced number of tests, and meteorological conditions that fluctuated considerably because it was raining on-site at the time of testing.

\section{CONCLUSIONS}

In this study, it was observed that the energy use of a PPS-VSD can be optimized by sharing the variable speed drive with two different drive loads in a piece of agricultural equipment. From the tests performed using the cassava grater with two engines of $368 \mathrm{~W}$ and $736 \mathrm{~W}$, it was observed that the cassava can be grated in scenarios of mean irradiance as low as $200 \mathrm{~W} \mathrm{~m}^{-2}$; however, the motor 
pump can pump water only when the irradiance is higher than $375 \mathrm{~W} \mathrm{~m}^{-2}$. This demonstrates the feasibility of the complementary use of this agricultural equipment in a PPS-VSD.

As for programming and adjustments made to the PID controller, they are compatible with both the motors used in this study. Therefore, the application becomes easy to operate for the end-user and is therefore suitable for the rural sector.

\section{ACKNOWLEDGEMENTS}

We thank Professor Samuel Benchimol and the Amazon Bank of Conscious Entrepreneurship awards, 2018 edition, for the award and resources that made this study possible.

\section{REFERENCES}

Antonello R, Carraro M, Costabeber A, Tinazzi F, Zigliotto M (2016) Energy-Efficient Autonomous Solar Water-Pumping System for Permanent-Magnet Synchronous Motors. IEEE Transactions on Industrial Electronics 64(1):43-51.

Brito AU, Zilles R (2005) Systematized Procedure for Parameter Characterization of a Variable-speed Drive Used in Photovoltaic Pumping Applications. Progress in Photovoltaics: Research and Applications 14(3):195-287.

Chandel SS, Naik MN, Chandel R (2015) Review of solar photovoltaic water pumping system technology for irrigation and community drinking water supplies. Renewable and Sustainable Energy Reviews 49:1084-1099.
Driemeier C, Zilles R (2010) Six-element circuit for maximum power point tracking in photovoltaic-motor systems with variable-frequency drives. Progress in Photovoltaics: Research and Applications 18(2):107-114.

Fedrizzi MC, Ribeiro FS, Zilles R (2009) Lessons from field experiences with photovoltaic pumping systems in traditional communities. Energy for Sustainable Development 13:64-70.

Maranhão GNA, Brito AU, Leal AM, Fonseca JKS, Macêdo WM (2015) Using LDR as Sensing Element for an External Fuzzy Controller Applied in Photovoltaic Pumping Systems with Variable-Speed Drives. Sensors 15:24445-24457.

Maranhão GNA, Brito AU, Pinho JT, Fonseca JKS, Leal AM, Macêdo WM (2016) Experimental Results of a Fuzzy Controlled Variable-Speed Drive for Photovoltaic Pumping Systems: A Review. IEEE Sensors Council 16(9):2854-2864.

Valer LR, Melendez TA, Fedrizzi MC, Zilles R, Moraes AM (2016) Variable-speed drives in photovoltaic pumping systems for irrigation in Brazil. Sustainable Energy Technologies and Assessments 15:20-26.

Yahyaoui I, Atieh A, Tadeo F, Tina GM (2017) Energetic and economic sensitivity analysis for photovoltaic water pumping systems. Solar Energy 144:376-391. 